\title{
INTERROGANDO A BRANQUITUDE: experiências formadoras em raça, etnia, religião e sexualidade de um garoto branco, cristão e gay
}

\begin{abstract}
André Sidnei Musskopf ${ }^{1}$
Resumo: Uma das questões pouco investigadas nos estudos pós-coloniais e decoloniais é a constituição da branquitude e seu papel na manutenção das estruturas de dominação e exploração. Nesse artigo analisa-se como raça e etnia se constituem em relação à religião e como se articulam com questões de gênero e sexualidade a partir de um relato autobiográfico que se concentra na infância. A construção do relato está fundamentada na metodologia de "pesquisa-formação" de Marie-Christine Josso e apresenta "experiências formadoras" que evidenciam de que forma as questões enunciadas vão se materializando na formação do sujeito que narra em forma de pedagogias. O objetivo dessa abordagem e das informações apresentadas é oferecer subsídios para a construção de processos educativos que questionem a colonialidade e favoreçam perspectivas libertadoras e emancipatórias.
\end{abstract}

Palavras-chave: Branquitude; Experiências Formadoras; Childhood.

\section{INTERROGATING WHITENESS: formative experiences in race, ethnicity, religion and sexuality of a white, Christian, gay boy}

\begin{abstract}
One of the issues little investigated in the post-colonial and decolonial studies is the constitution of whiteness and its role in the maintenance of the structures of domination and exploitation. This article analyzes how race and ethnicity are constituted in relation to religion and how they are articulated with issues of gender and sexuality from an autobiographical narrative focused on childhood. The construction of the narrative is based in Marie-Christine Josso's "research-formation" methodology and presents "formative experiences" that make evident how the issues referred materialize in the formation of the subject that tells the story in form of pedagogies. The goal of this approach and the information presented is to offer subsidies for the construction of educational processes that question coloniality and favor liberating and emancipatory perspectives.
\end{abstract}

Keywords: Whiteness; Formative Experiences; Childhood.

\section{Introdução: Caminhar para si}

Os estudos pós-coloniais e, de modo especial, os estudos decoloniais na América Latina, têm desafiado a reflexão teórica e prática em diversos temas e áreas do conhecimento (BAPTISTA, 2016). O paradigma da interseccionalidade (BIROLI; MIGUEL, 2015) também tem apontado para a necessidade de perceber e estabelecer múltiplas conexões para entender fenômenos e processos políticos, sociais, culturais e, por extensão, pedagógicos. Na crítica decolonial, capitalismo, racismo e patriarcado (ou classe, raça e gênero/sexualidade) apresentam-se como elementos-chave para pensar a história e seu legado na realidade atual (SEGATO, 2013). Entender suas origens e seus mecanismos de articulação e atualização abre caminho para compreensões mais profundas sobre as experiências de indivíduos e grupos sociais e a realidade de relações desiguais, violentas e injustas. Além disso, permite vislumbrar perspectivas de superação dessas formas de relação a partir de práticas emancipadoras e libertadoras, inclusive no campo da Educação.

\footnotetext{
${ }^{1}$ Doutor em Teologia e Docente do Programa de Pós-Graduação em Teologia da Faculdades EST.
} 
Tais questionamentos e desenvolvimentos no âmbito da reflexão teórica e da prática política, e da relação entre elas, também têm exposto limitações de produções que privilegiam um elemento ou dimensão em relação aos outros. As abordagens a partir das experiências de gays e lésbicas (e também queer) foram e são questionadas por sua não rara incapacidade de articular questões mais complexas em relação à sexualidade (a experiência de pessoas bissexuais, por exemplo), a gênero (a experiência de pessoas trans, por exemplo) e a sexo (a experiência de pessoas transexuais e intersexuais, por exemplo) (SAPRGO, 1999), mas também suas perspectivas heteronormativas, homonormativas e assimilacionistas e, não menos importante, seus pressupostos em relação a classe e raça e etnia ${ }^{2}$ (privilegiando, muitas vezes, a experiência de pessoas brancas de classe média). A mesma crítica tem estado presente nos estudos feministas, expressa em sua diversidade de correntes e perspectivas (feminismo negro, comunitário, classista, ecológico, por exemplo) (RIBEIRO, 2018).

Como pesquisador na grande área dos estudos sobre diversidade sexual e de gênero $^{3}$ e, mais especificamente, no campo dos estudos sobre religião, mas ao mesmo tempo como homem branco e cisgênero com acesso a determinados bens materiais e culturais, esses questionamentos também têm estado presentes nas minhas reflexões e vivências. Ainda assim, apesar de me identificar como um homem gay e assumir essa experiência como lugar de produção de conhecimento e atuação política, ou exatamente por isso, reconheço que especialmente questões relacionadas a raça e etnia não têm sido substancialmente refletidas, particularmente porque, como já apontaram várias pessoas e estudos, a identificação como pessoa branca (dificilmente identificada como "raça") e o pertencimento a determinada etnia (nesse caso frequentemente exaltada) raramente se tornam objeto de reflexão. Isso se deve ao fato de esses elementos ou dimensões estarem localizados no marco de padrões hegemônicos e naturalizados como ideais e, por isso, não questionados (TOWNES, 2010). O mesmo ocorre com estudos e reflexões sobre masculinidades, especialmente quando partem e privilegiam as experiências de homens identificados como heterossexuais, sem pensar sua relação com pessoas e

\footnotetext{
${ }^{2}$ Há uma longa e importante discussão sobre os termos e conceitos "raça" e "etnia", bem como sobre a relação entre eles (NASH, 2013). Utilizo, nesse texto, os termos em conjunto respeitando tanto as diferenças quanto a pertinência da utilização de cada um.

${ }^{3}$ Utilizo "diversidade sexual e de gênero" para referir-me à grande área que inclui estudos feministas, gays, lésbicos, queer e, também, gênero e sexualidade como dimensões que, embora sejam abordadas separadamente como categorias analíticas, estão interligadas e não podem ser tomadas como essencialmente diferentes, seguindo os questionamentos levantados pelos estudos queer em relação ao uso de "gênero" e os riscos de reificar o padrão heteronormativo (por exemplo BUTLER, 1999; BUTLER, 2004).
} 
experiências que se identificam ou são identificadas fora do padrão heteronormativo (MUSSKOPF, 2000).

Por esse motivo, essas questões têm estado presente nas minhas reflexões há algum tempo, apontando para a necessidade de refletir criticamente sobre como elementos de classe, raça e etnia interferem na construção de identidades e identificações e nas relações estabelecidas a partir delas não apenas a partir das vivências e reflexões originadas na margem dos sistemas dominantes, ainda que informado por elas, mas desde vivências e reflexões que têm consciência de seu status privilegiado nesses sistemas, ainda que não cumpram com todos os requisitos predeterminados (ou mesmo sabendo que, de fato, ninguém os "cumpre" verdadeira e totalmente, mas suas performances sociais, críveis e reconhecidas, determinam um lugar privilegiado nas escalas da hierarquia social).

Nesse artigo, proponho um exercício reflexivo sobre essas questões a partir da proposta de "pesquisa-formação" de Marie-Christine Josso. Segundo a autora:

A mudança oferecida no quadro de uma Pesquisa-formação é uma transformação do sujeito aprendente pela tomada de consciência de que ele é e foi sujeito de suas transformações; em outras palavras, a Pesquisa-formação é uma metodologia de abordagem do sujeito consciencial, de suas dinâmicas de ser no mundo em diferentes contextos que são/foram os seus. (JOSSO, 2010, p. 125)

A metodologia proposta pela autora permite identificar "experiências formadoras" que, por um lado, evidenciam o processo de formação experimentado e, por outro lado, permitem a construção de projetos de conhecimento que reconheçam e valorizem as experiências vividas e os trajetos percorridos, mas também permitam a crítica a esses processos e seus efeitos de maneira individual e coletiva e sua reconfiguração, tendo como base a tomada de consciência sobre determinadas questões. Nesse sentido:

A formação experiencial designa a atividade consciente de um sujeito que efetua uma aprendizagem imprevista ou involuntária em termos de competências existenciais (somáticas, afetivas, conscienciais), instrumentais ou pragmáticas, explicativas ou compreensivas na ocasião de um acontecimento, de uma situação, de uma atividade que coloca o aprendente em interações consigo mesmo, com os outros, e com o meio ou com as coisas, num ou em vários registros. (JOSSO, 2004, p. 56-57) ${ }^{4}$

\footnotetext{
${ }^{4}$ A autora diferencia "vivências" de "experiências". Segundo ela: "O termo vivência é reservado para aqui designar o conjunto dessas implicações ou interações semeadas diariamente ao longo de nossas vidas. O termo experiência é, por sua vez, empregado para designar a atividade específica que consiste em analisar uma ou várias vivências para delas extrair conhecimentos e/ou informações" (JOSSO, 2010, p. 266).
} 
Como a própria metodologia indica, não se trata de encontrar e definir uma versão acabada e definitiva sobre os processos de formação e sua utilização no campo da Educação, mas da problematização desses processos e a contínua necessidade de sua revisão.

O elemento da religião aparece, nesse caso, tanto como integrante e fundamente dos processos de formação em âmbito pessoal, quanto como objeto de estudo evidenciado na trajetória acadêmica de quem realiza esse exercício de reflexão. Nesse sentido, a discussão aqui proposta parte e fundamenta-se no exercício de narrativa autobiográfica para, a partir dele, estabelecer pontos de inflexão sobre as temáticas enunciadas e discutir seus desafios e possibilidades no campo da Educação.

\section{A (des)construção de um "alemãozinho"}

Lembro da minha infância como uma fase muito boa da minha vida. Em meus exercícios de relembrar e dar sentido às experiências desse período, muitas das quais dependem de informações e narrativas de outras pessoas, percebo como muitas experiências vividas foram marcantes para os períodos subsequentes e, também, com relação a quem eu sou hoje. Não pretendo, aqui, fazer um relato autobiográfico completo ou definitivo da minha infância e seus impactos na minha vida adulta, mas identificar vivências que, ao serem refletidas e trazidas ao nível da consciência, tornamse "experiências formadoras" que me ajudam a pensar os processos de formação e as pedagogias implícitas, particularmente no que diz respeito à raça e etnia, sexualidade e de que forma a religião ou a religiosidade participam e se misturam a essas questões.

Recentemente, em conversa com minha mãe, pude reconstruir alguns passos da minha primeira infância. Minhas memórias fragmentadas dessa fase da minha vida foram preenchidas e organizadas a partir do seu olhar e sua memória sobre esse período de nossas vidas. Embora a minha referência de "lugar de origem" seja uma pequena cidade no interior do Rio Grande do Sul, à época com aproximadamente 20.000 habitantes, o registro na minha certidão de nascimento e em outros documentos que trazem essa informação revela que eu nasci em uma cidade de porte médio da região metropolitana de Porto Alegre. Nos anos de 1970, meu pai e minha mãe, primeiro separadamente e depois em conjunto, migraram para essa cidade para trabalhar em fábricas de calçado. Eram relativamente jovens para os padrões de hoje, mas não para os padrões da época, especialmente para quem vinha de uma cidade do interior e não 
tinha muitas perspectivas de continuidade nos estudos ou trabalho. ${ }^{5}$ Apesar de minhas primeiras lembranças desse período serem dessa cidade e de pessoas que conheci lá, segundo o relato de minha mãe, antes de eu completar seis anos, ela, meu pai e eu moramos em três lugares diferentes lá e ainda em outros dois lugares na sua cidade de origem e que se tornariam a minha de referência. De fato, nesses primeiros anos e em várias ocasiões na minha adolescência e vida adulta, eu morei em diversos lugares e convivi com diferentes pessoas.

O que quero destacar aqui não é precisamente a mobilidade da minha família, algo que seguramente também teve impacto na minha formação, inclusive em outros períodos da minha vida, mas o fato de ter vivido em dois contextos bastante distintos e as vivências que isso me proporcionou em termos de entendimentos sobre origens, raça e etnia e classe social. O lugar onde nasci e onde morei até os cinco anos de idade caracteriza-se, ainda hoje, por ser um lugar para onde muitas pessoas vindas do interior migram para trabalhar em indústrias. A isso soma-se o fato de ser uma cidade urbanizada e, assim, com as características de um centro urbano e industrial marcado por uma relativa diversidade de pessoas e grupos sociais e também por diversas situações de precariedade. Minha mãe e meu pai viveram em pensões, alugaram uma "peça" nos fundos de uma outra casa e depois foram morar em uma casa num loteamento popular construído pela administração pública. Ainda lembro que nossa casa ficava bem no alto de um morro do qual se via todas as casas praticamente iguais enfileiradas, a terra vermelha quase amarela e a ausência quase total de árvores e vegetação. Lá embaixo ficava uma área com algum verde e uma creche que eu frequentei por algum tempo.

Ainda que o que tenha me marcado nesse período não seja necessariamente uma grande diversidade étnica e racial, pois aparentemente minha mãe e meu pai se moviam em círculos formados de outras pessoas com ascendências parecidas, havia uma diversidade de pessoas e de origens que faziam parte da minha vida. Duas madrinhas e um padrinho que eu fiquei posteriormente muito tempo sem ver e sem ter contato e que no meu imaginário permaneceram como essas pessoas que viviam numa cidade grande e me causavam certa intriga e curiosidade, histórias da vizinhança que eram evocadas em conversas, e o trânsito de pessoas nos lugares em que moramos, seja porque eventualmente alugávamos um quarto ou hospedávamos alguém que, como meu pai e

\footnotetext{
${ }^{5}$ Minha mãe apenas terminou o Ensino Médio anos mais tarde e uma de minhas tias foi a única pessoa daquela geração a ter acesso e concluir o Ensino Superior.
} 
minha mãe, vinha do interior e precisava de um lugar para ficar até se estabelecer (ou retornar para seu lugar de origem, o que não era incomum). Em nosso último endereço nessa cidade convivia com duas crianças da casa vizinha (e outras na creche) que não eram "tão brancas como a gente" e que frequentemente eram alvo de comentários que tinham a ver com sua origem e aparência. Apenas mais tarde fui entender porque, muitas vezes, se referia a essas pessoas como "brasileiros" e "brasileiras". Havia ali elementos de diferenciação dos quais não tenho necessariamente uma lembrança negativa, mas que foram parte das vivências desse período.

Pelo menos parte desses elementos de diferenciação foram ficando mais evidentes assim que retornamos para a cidade natal de minha mãe e de meu pai. Uma cidade formada basicamente por imigrantes alemães que vieram para o Brasil no século XIX e que "colonizaram" toda a região e seus e suas descendentes. Apesar da minha pele branca, meus olhos azuis e meu cabelo loiro (quase dourado), até mesmo eu às vezes era visto como "diferente" por ter nascido e vivido em um lugar distante, urbano, ao qual a maioria das pessoas, e especialmente as crianças, não tinham acesso a não ser por relatos (nem sempre totalmente precisos ou isentos de alguma característica lendária) das pessoas que voltavam de lugares como esse. ${ }^{6}$ De fato, do meu período de infância não tenho muitas recordações de conviver com pessoas de outras origens étnicas e raciais. Do primeiro ano após o retorno à cidade de origem de minha mãe e de meu pai, quando morei com meu avô materno e minha avó materna, lembro da fascinação com alguns objetos indígenas (especialmente pontas de flechas e lanças e alguns potes de madeira) encontrados durante a retirada de terra da margem do rio para a produção de tijolos na olaria em que ele, ela e meu bisavô trabalhavam e da qual eram proprietários e proprietária, a mesma que para mim era um misto de lugar de diversão (especialmente nos grandes galpões nos quais os tijolos de barro secavam antes de serem queimados do forno - esse não acessível a mim) e de iniciação ao mundo do trabalho (muito cedo eu passei a "ajudar" nas lides da olaria). ${ }^{7}$ Mas, tirando as

\footnotetext{
${ }^{6}$ Uma das histórias que marcou muito minha infância e adolescência foi a de uma tia que emigrou para "a cidade grande" devido a brigas familiares e da qual se suspeitava (e muitas pessoas atestavam com convicção) que vivia da prostituição. Era vista como "louca", "mulher de má vida", e suas visitas eram sempre alvo de comoção familiar. Há muitos mistérios envolvendo a vida dessa tia, já falecida, e que, em algum momento, eu gostaria de resgatar justamente pelos estereótipos de gênero e sexualidade que marcaram a sua vida e, em certo sentido, a privaram da convivência familiar e comunitária, inclusive de seu filho que ficou aos cuidados da avó.

${ }^{7}$ Embora meu avô e minha avó tivessem uma "fábrica de tijolos", vivam numa região rural e, junto com a olaria, plantavam e tinham diversos animais. Com primos e primas, eu ajudava na colheita, tirava leite de vacas, colhia e comia todos os tipos de frutas diretamente das árvores e, em raras ocasiões quando era permitido, nadava no rio e até pescava.
} 
atividades de "dia do índio" na escola, quando colocávamos saias de papelão com penas coloridas, cocares na cabeça e tinta no rosto, a realidade de povos e pessoas indígenas não passava de uma lenda distante que não tinha relação com a vida de então. ${ }^{8}$

Foi só quando me mudei para uma outra parte da cidade (que à época parecia muito longe da casa de minha avó e meu avô, pois, em geral, só visitava nas férias e só havia um ou dois ônibus por dia para fazer o trajeto) que esse elemento de diferenciação étnica e racial ficou mais forte. Ali também havia várias fábricas de calçado (motivo pelo qual muitas pessoas que tinham emigrado agora retornavam e que fazia, também, com que a cidade agora virasse alvo de migrantes de outros lugares) e um início de urbanização com pessoas de diversas origens. Comecei a frequentar a escola regular $\left(1^{\mathrm{a}}\right.$ série) numa escola evangélica ${ }^{9}$ e tinha vários amigos e várias amigas com os e as quais brincava na vizinhança. Frequentei essa escola até a $5^{\text {a }}$ série e morei nesse lugar até os 12 anos de idade, quando nos mudamos para uma casa bastante simples e reformada para nossa vinda, que antes havia servido de residência para uma família que trabalhava na olaria de meu avô e minha avó e com a qual não tive muito contato durante o período em que vivi lá anteriormente, mas guardo na memória que havia uma interdição para que eu não me "misturasse" com aquela família e não brincasse com as crianças que ali viviam - o que só despertava ainda mais minha curiosidade.

Seguindo os estereótipos e padrões de gênero, nessa nova realidade eu passava muito tempo brincando na rua com os meninos da vizinhança, inclusive porque meu pai e minha mãe trabalhavam o dia todo, saíam muito cedo e só retornavam à noite. Jogávamos futebol, bolinha de gude, taco, andávamos de bicicleta e outras brincadeiras “próprias de meninos". Na mesma rua havia um armazém (onde comprávamos sorvete seco e pipoca doce) e um salão de baile com um bar. Entre o armazém e o salão com o bar havia duas casas nas quais moravam famílias negras. A relação entre as famílias, de

\footnotetext{
${ }^{8}$ Não faltou na minha infância, especialmente no período em que vivi com meu avô materno e minha avó materna e em que caminhava três quilômetros para chegar até a escola onde frequentava o pré-escolar (parte desse trajeto feito sozinho, pois a minha casa era a que ficava mais longe), a lenda sobre os povos ciganos que sequestravam crianças em Kombis brancas para extrair seu sangue e fazer outras maldades que me atormentava em todo o trajeto de volta da escola e, por vezes, me fazia voltar correndo o trecho em que não tinha a companhia de meus e minhas colegas.

9 "Escola evangélica" refere-se, nesse contexto, a escolas criadas pelos e pelas imigrantes nas colônias uma vez que havia ausência quase total do Estado e, inclusive, interdições quanto às práticas religiosas e ao reconhecimento civil (as igrejas protestantes não podiam ter torres, casamentos nessas igrejas não eram reconhecidos pelo Estado, entre outras questões). É muito comum encontrar, nas comunidades e cidades formadas por descendentes desses e dessas imigrantes, o prédio da igreja, o cemitério e uma escola construídas pela própria comunidade e em terras doadas por alguém da mesma ou compradas de forma comunitária. Grande parte dessas escolas e comunidades religiosas vieram a fazer parte da Igreja Evangélica de Confissão Luterana no Brasil e hoje fazem parte da Rede Sinodal de Educação (veja DREHER, 1984; DREHER, 1999; WITT, 1996).
} 
modo geral, era tranquila e as famílias negras eram muitas vezes referidas como exemplo, especialmente para as crianças, pois destacava-se seu esforço, seu cuidado com a casa e as roupas e o fato de as pessoas mais jovens se referirem às pessoas mais velhas como "senhor" ou "senhora", visto como um ato de profundo respeito e obediência. Ainda assim, as crianças dessas famílias não frequentavam a mesma escola que eu e alguns dos meus amigos de pele clara como a minha, assim como outros de pele menos clara que a minha. Frequentavam a escola pública, onde estudavam, em geral, as filhas e os filhos de "brasileiros" e "brasileiras" (o que significava "sem uma ascendência germânica evidente pela cor da pele ou pelo sobrenome"). Estudar na escola pública com "negros" e "negras" e "brasileiros" e "brasileiras" podia ser uma vergonha e pairava como uma ameaça quando as contas não fechavam e faltava dinheiro para a mensalidade na escola privada (e evangélica).

Nessa época eu também visitava com maior frequência a minha avó paterna, pois as terras onde ela morava com filhos, filhas, netos e netas ficavam mais próximas à minha casa e eu podia ir de bicicleta (num caminho que à época também parecia muito longo e fazia que eu me sentisse um quase herói vivendo a aventura de ir sozinho até lá). Próximo às terras da minha avó morava uma outra família negra num arranjo que eu nunca entendi muito bem. Havia, também nesse caso, uma certa "aura" ao redor dessa família com a qual não tínhamos muito contato, a não ser pela relação de amizade de meu pai com os rapazes daquela família, seja por trabalharem juntos na fábrica ou pelo futebol. Das poucas vezes em que estive na casa e nas terras dessa família e dos comentários que se fazia sobre ela, lembro que naquele lugar coabitavam muitas pessoas de várias gerações e que todo o espaço de convivência era muito singular quando comparado com o que eu estava acostumado: lembro de uma casa muito pequena, com estrutura frágil, sem muitas divisões internas, chão de barro, fogão à lenha construído ali mesmo, mobiliário muito simples, uma árvore grande e um pátio cheio de animais, crianças e objetos de todo tipo. Além da sensação de profundo respeito com relação às pessoas mais idosas, me chamava a atenção como aquelas pessoas pareciam felizes e como era expressivo o seu sorriso (se não me engano, esse era, inclusive, o apelido de um dos rapazes - "sorriso"). ${ }^{10}$

Foi nesse contexto que eu fui tomando consciência de uma identidade que, em

\footnotetext{
10 Hoje entendo que se tratava de um quilombo, possivelmente com remanescentes de pessoas escravizadas, como outros que já conheci. Outra parte da minha infância que gostaria de revisitar com mais profundidade.
} 
fases posteriores da minha vida eu muitas vezes tentei negar ou dissimular: em vários espaços eu passei a ser identificado como "alemãozinho". Em meus momentos de revolta infantojuvenil com relação a essa identidade quase imposta, inclusive quando deixei de falar alemão ${ }^{11}$, eu afirmava que era "brasileiro", tinha nascido no Brasil, não era e não queria ser "alemãozinho". Eu queria ser "brasileiro", até porque a vida das pessoas consideradas "brasileiras" me parecia muito mais interessante do que a de minha família e comunidade, marcadas profundamente por uma ética rigorosa de trabalho e de comportamento, aquela à qual se refere Max Weber em A ética protestante e o espírito do capitalismo (WEBER, 2007). Não foi senão muito mais tarde que percebi todos os privilégios e oportunidades que essa minha identidade percebida e que eu de diversas formas performava me garantia e ainda me garante. Ainda houve outras vivências envolvendo pessoas negras que me marcaram, como o breve relacionamento que minha mãe teve com um homem negro e a comoção que gerou; e o seu casamento com meu padrasto identificado por muitos como "canela"12; a comoção na família de meu padrasto porque uma de suas irmãs namorava um homem negro com quem veio a se casar e cujo casamento foi "aceito" apenas porque ela estava grávida e seria uma desonra maior ser mãe solteira ${ }^{13}$; e, já na minha adolescência, a existência de uma "vila", apelidada de "Flamengo", num espaço precariamente urbanizado $^{14}$ no caminho entre a minha escola e o lugar onde morava e pela qual era recomendado não passar e não ter relações com as pessoas que lá moravam (negras). Todas essas vivências, e provavelmente outras, me deixavam intrigado e, ao mesmo tempo, fascinado, mas o que elas inevitavelmente me diziam era que havia uma diferença fundamental entre mim, o alemãozinho, e eles e elas (os negros e as negras,

\footnotetext{
${ }^{11}$ Provavelmente por volta dos 10/12 anos de idade eu decidi, não sei bem porque, parar de falar a língua alemã (ou o dialeto falado em minha família) que, até onde sei foi, minha língua materna, sendo que minha bisavó não falava ou entendia português. Eu voltei a falar alemão quando eu tinha 13 anos, pois minha mãe conseguiu um emprego em uma loja/oficina de moveis, motosserras e máquinas agrícolas para mim e um dos requisitos era falar alemão para se comunicar com clientes. Mais tarde eu também optaria por estudar inglês na Faculdades de Teologia, mesmo que fosse quase um pré-requisito para a atuação como pastor na igreja falar alemão, para desespero de minha avó. Falarei mais sobre a questão religiosa abaixo.

12 "Canela", nesse contexto, se refere a pessoas de pele mais escura (não negra).

${ }^{13} \mathrm{Um}$ elemento interessante dessa história é que o namorado e marido da irmão do meu padrasto era integrante de uma família negra muito conhecida na cidade porque seus membros falavam alemão, o pai e a mãe eram exaltado e exaltada por trabalharem honesta e obedientemente (exemplos de trabalhador e trabalhadora), e por criarem seus filhos e suas filhas rigidamente sob os mesmos padrões de decência e honestidade. Não raro eram referidos e referidas como negros e negras "de alma branca" ou outras expressões que as e os colocavam em outro lugar no imaginário social, ainda que não igualados e igualadas às pessoas e famílias brancas.

${ }^{14}$ Essa vila, habitada por diversas famílias, era sempre referida como um lugar associado à violência, criminalidade e à venda e consumo de drogas.
} 
canelas, bugres, brasileiros e brasileiras).

Uma noção mais evidente e consolidada de minha "branquitude" eu vim a desenvolver mais tarde em minha primeira experiência fora do Brasil como intercambista nos Estados Unidos da América. Desde o tratamento recebido na imigração (visivelmente diferente daquele dispensado a pessoas não-brancas e experimentado em diversas ocasiões posteriormente) até o fato de falarem comigo em inglês em lojas e restaurantes em bairros ou comunidades brasileiras e/ou latinas (o que também experimento quando viajo para o norte e nordeste do Brasil). Mesmo quando eu me comunicava em português ou espanhol, tudo confirmava não apenas que eu era branco (o que é um dado real), mas que a percepção dessa branquitude definia o tipo de relação que era estabelecida comigo. Não menos impactante e formador de minha consciência foi o fato de morar em um bairro negro - enquanto realizava estágio numa igreja em que apenas eu, o pastor e mais duas ou três pessoas eram brancas - de geralmente ser a única pessoa branca no ônibus que me levava até a estação central e de que, mesmo cruzando a fronteira da cidade para o lado brasileiro e latino, eu continuava sendo "um gringo". Desse período, um dos mais importante da minha formação adulta, há muitas outras histórias para contar, mas como o foco dessa narrativa e reflexão é minha infância vou retornar a essa fase.

Em todas as situações e vivências descritas até aqui se evidenciam também questões muito fortes de classe social. $\mathrm{O}$ fato de ser branco ou descender de uma família de muitos sobrenomes de origem alemã (até onde pude averiguar eu faço parte da oitava geração desde que a primeira pessoa de minha família materna chegou ao Brasil), e viver em uma comunidade formada em grande parte por pessoas com as mesmas características, não necessariamente significava um lugar confortável na escala da hierarquia social. Há várias histórias relacionadas a minhas antepassadas e a meus antepassados que fizeram com que a minha família (referindo-se especialmente a eu, meu pai e minha mãe) não comungássemos do status das famílias mais abastadas ou reconhecidas em nossas comunidades. A própria migração de meu pai e minha mãe, os lugares onde moramos e as condições em que vivemos na minha primeira infância evidenciam isso. Não foram tempos fáceis. Mas nossa situação não era tão diferente da maioria de pessoas com as quais convivíamos e que ali estavam pelos mesmos motivos (com importantes exceções). O retorno à cidade de origem de minha mãe e de meu pai não significou uma mudança substancial nesse sentido. Depois de viver um ano com meu avô materno e minha avó materna porque minha mãe (nessa época separada do 
meu pai) foi morar com amigas em uma república e meu pai foi morar com sua família enquanto ela e ele trabalhavam em fábricas de calçado, a nova mudança e a entrada na escola regular também logo evidenciaram meu pertencimento a um estrato social diferente pela convivência com colegas e suas famílias. Até muito tarde na minha adolescência lembro de minha mãe me questionando sobre o fato de eu (segundo ela) sempre me relacionar com pessoas (amizades na escola ou fora dela) com poder aquisitivo superior ao nosso o que, também segundo ela, fazia com que eu tivesse "manias de rico". Isso era, supostamente, um incentivo para que eu me esforçasse para “atingir" ou "conquistar" um certo nível através do meu esforço e do meu trabalho (identificado na infância com a dedicação aos estudos, a realização de tarefas domésticas com rigorosidade e, ocasionalmente, alguma atividade que gerasse alguma renda extra) ou uma compensação para o fato de que havia pessoas que estavam em situação "muito pior" (geralmente "os brasileiros" e "as brasileiras").

Como meu próprio relato evidencia, todas essas questões também me intrigavam e, não raro, me deixavam confuso e irritado com o meu lugar social. Foi também no meu período de intercâmbio, depois de ter me negado a falar alemão na minha adolescência e ter me negado a estudar alemão na Faculdade (fatos que por si só me tornavam meio "estranho" no contexto familiar e comunitário), que outra vivência me ajudou a entender e me posicionar melhor com relação a essas questões. Nos Estados Unidos da América, por vias bastante complexas e quase inimagináveis, tive a oportunidade de conhecer um casal de pessoas idosas que residiam numa comunidade para pessoas aposentadas e que eram descendentes de um dos irmãos ou uma das irmãs (não tenho certeza) que migrou para o Brasil no século XIX. Ele e ela guardavam correspondências enviadas da pessoa que vivia no Brasil à pessoa que vivia nos EUA. As cartas contavam, com uma relativa fartura de detalhes, as experiências desses primeiros e dessas primeiras imigrantes ao Brasil até o nascimento de minha bisavó que, eu soube, por muito pouco não veio a falecer logo após o nascimento. Em várias tardes de difícil leitura (as cartas estavam escritas em algo próximo ao alemão gótico) eu fui descobrindo como foi a vida de pelos menos parte de minhas antepassadas e meus antepassados desde o período em que ainda viviam na Alemanha (guardado em memórias) até as dificuldades e desafios enfrentados na "nova terra". Eu era e sou descendente de pessoas empobrecidas em seu país de origem (Sem-Terra, como eu gosto de dizer para incomodar minha avó que ainda tem medo que comunistas invadam e tomem seus bens que a esta altura já são bem poucos) que viveram em condições 
absolutamente precárias e lidaram com a ameaça de morte sempre muito perto.

De longe, essa tomada de consciência não serviu para justificar os meus incômodos e questionamentos com relação às narrativas gloriosas sobre um povo bravo, destemido e trabalhador (diferente dos povos nativos ou sequestrados e escravizados por muitas dessas mesmas famílias e grupos teuto-brasileiros), contadas na escola, na igreja, nos grupos de dança típicas e folclore alemão, nos festejos familiares e comunitários, todos os espaços pelos quais circulei. Pelo contrário, me ajudou e me ajuda a perceber justamente como a experiência de privação e marginalização de um povo ou de uma comunidade pode ser usada para justificar o seu sentimento de superioridade sobre outros grupos e comunidades, particularmente em relação à raça e etnia. Mas, mais do que isso, evidenciou a multidimensionalidade desse sistema de organização social baseado na raça e na etnia e seu entrecruzamento com outros elementos e dimensões que compõem as identidades e lugares sociais, mesmo de um menino branco e "alemãozinho". Além da questão de classe social, aqui é que entram os elementos de gênero e sexualidade e a sua relação com a questão religiosa.

\section{Um alemãozinho meio torto}

O primeiro capítulo de minha tese de doutorado, publicada em livro, inicia com uma breve narrativa sobre como experimentei o tema da sexualidade e da religiosidade no meu contexto familiar, particularmente na minha infância. Ali descrevo de que forma essas duas dimensões da minha experiência foram marcadas pelo que chamo de "ambiguidade", o que depois passo a descrever como uma característica daquilo que chamo de sexualidade e religiosidade brasileiras. O objetivo é mostrar como elas são compreendidas e vividas com relativa fluidez e pluralidade, mas também como a relação entre elas se dá de forma ambígua, fluída e plural (MUSSKOPF, 2012, p. 35166). Da mesma forma, não é possível entender o relato anterior, que enfoca questões de raça, etnia e classe social, particularmente na minha trajetória pessoal e nas minhas experiências formadoras, sem relacioná-las com questões de sexualidade e religião.

O elemento religioso sempre esteve muito presente na minha vida. Minhas primeiras lembranças são das orações diárias, antes de dormir, realizadas em alemão com minha mãe ou minha avó materna. No entanto, uma vivência mais concreta e regular se deu apenas depois de nosso retorno para a cidade de origem de minha mãe e meu pai. Enquanto vivia com minha avó materna e meu avô materno, frequentava, com 
certa regularidade, as atividades religiosas da localidade, particularmente as festividades. Ao mudar para o novo bairro lembro que passei a frequentar o "culto infantil" (também conhecido como escola dominical), mesmo que minha mãe não fosse tão assídua aos cultos para pessoas adultas. Lembro dessa experiência com leveza e como um espaço em que me sentia bem, pois além de conviver com colegas da escola, ouvia histórias, desenhava, brincava e, de vez em quando, participava de apresentações e atividades preparadas para as pessoas adultas na igreja. Quando nos mudamos novamente, eu passei a frequentar o Ensino Confirmatório ${ }^{15}$ e, posteriormente, o grupo de jovens da igreja. Foi essa vivência e esse caminho que me fizeram, posteriormente, ingressar na Faculdade de Teologia, talvez por motivos nem tão religiosos.

A participação na igreja e a passagem pelos diversos ritos não era apenas uma questão de crença. Fazia parte do percurso "natural" de todas as crianças e parte da identidade étnica e cultural local. Só se podia participar da Eucaristia depois de ter feito a Confirmação, momento em que madrinhas e padrinhos passavam a estar dispensadas e dispensados de dar presentes ao afilhado ou à afilhada. Ao mesmo tempo, significava a passagem para uma breve fase de juventude que não raro terminava não muito tempo depois com o ingresso no mundo do trabalho e, principalmente, com o casamento. ${ }^{16} \mathrm{~A}$ Confirmação, do ponto de vista mais social, também habilitava a participação em bailes, o consumo de bebidas alcoólicas e a iniciação sexual (vistas de forma diferente para meninos e meninas), que não raro aconteciam no salão paroquial da igreja ou nas proximidades, locais considerados mais apropriados para essas práticas e também mais comuns em termos de sociabilidade nesse contexto. Religião e identidade étnica e cultural estavam indissociavelmente conectadas e imbricadas uma na outra (DREHER, 1984).

Mas, apesar da aparência de estabilidade e linearidade, nem tudo era tão

\footnotetext{
15 Segundo Streck; Malacarne (2018, p. 129): "Nas comunidades da IECLB, o Ensino Confirmatório é um período que enfatiza a educação dos principais temas inerentes a fé cristã, segundo a perspectiva luterana. O processo culmina com uma celebração eucarística denominada de Confirmação. Neste momento, o e a adolescente confessam, publicamente, sua fé, além disso, são inseridos no mundo adulto comunitário. A dinâmica do Ensino Confirmatório e da Confirmação está relacionada com o Batismo e também compreende o principal momento de formação na IECLB. A constituição do Ensino Confirmatório/Confirmação (semelhante ao processo da Catequese na Igreja Católica Apostólica Romana) permitiu que este se consolidasse no período entre a infância e o mundo adulto. Tornou-se, assim, um rito de passagem entre os dois momentos do desenvolvimento humano".

${ }^{16}$ Eu mesmo comecei a trabalhar com 13 anos de idade (mesmo quando legalmente a idade para ingresso no mundo do trabalho era aos 14). O casamento muitas vezes era "antecipado" por conta de gravidez não planejada (um fenômeno bastante comum na minha família), o que podia ser visto como algo negativo para a moça (nem tanto para o rapaz), mas que logo era superado com um casamento de acordo com os padrões e o estabelecimento de uma nova família (como foi o caso de minha mãe e meu pai).
} 
tranquilo assim no universo das crenças. É verdade que a principal diferença que existia nesse contexto era a nítida distinção entre pessoas "evangélicas" e "católicas". O mundo do catolicismo, em geral, para uma criança evangélica era desconhecido e misterioso. Sabia-se que era algo a ser evitado tanto pelas práticas quanto pelas pessoas que assim se identificavam e viviam sua fé. ${ }^{17}$ Muitos conflitos familiares emergiam por conta de amizades entre crianças e jovens evangélicas e evangélicos e católicas e católicos e, principalmente, no caso de namoros e potenciais casamentos mistos (em termos étnico-raciais, mas também em termos religiosos denominacionais). A diferença também se acentuava na escola, quando o Ensino Religioso passou a ser ministrado segundo a confissão religiosa de estudantes (nesse caso havia apenas duas opções: o grupo de evangélicos e evangélicas e o grupo de católicos e católicas). No entanto, pelas experiências narradas acima, a convivência com pessoas católicas desde muito cedo fez parte de minhas vivências e não havia, pelo menos por parte de minha mãe, uma interdição com relação a isso, afinal ela mesma participava do circuito da "santinha" que circulava de casa em casa na vizinhança e por quem a família que a recebia era responsável durante algum tempo. Também minhas duas tias maternas se casaram "católicas" (devido à pertença religiosa de seus maridos) e eu fui pajem nas duas ocasiões.

Mas também havia outros roteiros religiosos muito mais escondidos e secretos que permeavam o subterrâneo religioso daquela comunidade e o meu próprio. ${ }^{18}$ Embora não lembre de ouvir nada sobre o assunto no contexto da minha família materna, sei de relatos de minha mãe que minha avó paterna, embora evangélica, era adepta de práticas de benzedura e que as recomendava para minha mãe. Eu lembro de acompanhar minha avó paterna pelo menos uma vez à casa de uma senhora para benzer minha prima que estava com manchas na pele e imagino que em outros momentos tenha participado de práticas semelhantes com ou sem o consentimento de minha mãe. Só muito tempo depois eu entendi que se tratava de alguma prática de cunho religioso e de que não era bem vista pelos espaços religiosos aos quais eu estava vinculado. Mas nunca o entendi como algo equivocado ou negativo, seja do ponto de vista da crença religiosa ou da pertença étnico-racial, uma vez que, ao longo dos anos, minha mãe foi construindo seu próprio mosaico de crenças e símbolos representado, por exemplo, na foto de sua

\footnotetext{
$17 \mathrm{Na}$ minha lembrança, em geral se tratava das mesmas pessoas e famílias identificadas como "brasileiras" no sentido étnico e racial. Mas também havia famílias de origem germânica identificadas com o catolicismo.

${ }^{18}$ Sobre "subterrâneo religioso" ver Bobsin (2016).
} 
estante que ilustra a tese de doutorado e o livro mencionados anteriormente e do que apenas tomei consciência quando uma certa pureza me passou a ser exigida do ponto de vista da religião. ${ }^{19}$

$\mathrm{O}$ fato de a religiosidade ser uma marca tão forte da identidade social e étnica no meio em que cresci também faz com que ela esteja fortemente misturada nas experiências relacionadas à sexualidade. Ser parte de determinado grupo étnico e, por extensão, religioso, também trazia implicações no âmbito das práticas, dos comportamentos e das identidades no campo da sexualidade. As linhas normativas estavam bem estabelecidas em relação àquilo que era esperado de cada indivíduo: namorar e casar com uma pessoa do "sexo oposto", (em princípio) não ter relações sexuais antes do casamento e constituir uma família com filhos e filhas. As exceções não eram raras e tratadas de maneira distinta pela família e pela comunidade, dependendo de vários outros elementos. ${ }^{20}$ Nesse sentido, as minhas vivências em questões de gênero e sexualidade também estiveram marcadas por essa perspectiva normativa, mas também por outras experiências suscitadas pelos contextos e relações em termos de raça, etnia e classe social.

Minhas primeiras memórias no âmbito da sexualidade como prática estão ligadas a brincadeiras com a vizinha que era um pouco mais velha do que eu na cidade em que nasci. Na cidade de origem de meu pai e minha mãe lembro de brincadeiras com primos, com colegas da escola e da vizinhança e minha iniciação solitária com masturbação. Nada muito diferentes de outras crianças e adolescentes do meu contexto e dessa época. Na minha família, como também descrito no relato anteriormente mencionado na tese de doutorado, não lembro da sexualidade como um tema tabu. Embora determinados assuntos ou práticas fossem objeto de eventuais repreensões ou desconfortos que, em geral, levavam ao silêncio, a vivência da sexualidade pelos membros da família próxima ou estendida, bem como de outras pessoas, não era algo que estava distante da realidade das crianças, mas, ao contrário, muito presente nas conversas geralmente em tom jocoso e de piada quando se comentava sobre a sexualidade (real ou imaginada) das outras pessoas (especialmente sobre meu bisavô e

\footnotetext{
${ }^{19}$ A foto que aparece em Musskopf (2012, p. 37) apresenta uma estante de sala com diversos objetos incluindo uma estátua de gesso de Jesus, uma estátua de Buda sentado sobre uma moeda, uma bruxinha, uma cestinha da fortuna e um elefante de costas para a porta.

${ }^{20}$ Não faltam aqui os exemplos de mulheres que engravidavam antes do casamento como mencionado acima, as solteironas e os solteirões com suas trajetórias misteriosas, relacionamentos extraconjugais de homens e mulheres, a masturbação e as brincadeiras sexuais entre meninos e outros em geral típicos de comunidades interioranas.
} 
minha bisavó ou meu avô e minha avó ou outras pessoas com mais idade e o interesse em saber se "ainda" mantinham relações sexuais e com que frequência).

A questão ficou mais complicada quando eu entrei para a escola. Já mencionei acima a evidente separação e, ao mesmo tempo, diferenciação étnica-racial e de classe da minha realidade escolar. Muito cedo ficou evidente que eu não pertencia ao grupo de crianças e famílias mais bem colocadas. Eu era uma das primeiras crianças a chegar na escola de manhã cedo e, muitas vezes, tive que esperar um longo tempo até que outras crianças chegassem e a própria escola começasse a funcionar. Minha mãe começava a trabalhar muito cedo e não tinha ninguém pra me levar à escola. Também não tinha ninguém que me buscasse e era minha tarefa voltar pra casa, o que aprendi a fazer sozinho. O tipo de roupas, o tipo de material escolar e brinquedos, o acesso a determinadas atividades me colocavam num lugar diferente. Minha resposta foi me dedicar aos estudos, tirar as melhores notas (inclusive que as meninas) e superar os meninos nas atividades e brincadeiras de competição (não ir bem nos estudos, causar problemas na escola e me envolver em brigas com os outros meninos, o que seria aceitável do ponto de vista de gênero, não era aceitável para minha mãe). Por causa das boas notas me aproximei das meninas e por causa do bom desempenho nas atividades competitivas despertei a ira dos meninos (em raras ocasiões admiração de meninos e meninas). Muito cedo, também, começaram as brincadeiras, acusações e xingamentos que, naquela época, não pareciam tão conscientes ou definidos, e giravam em torno de eu estar muito perto das meninas e querer ser "uma menininha". Também esse roteiro é bem conhecido e passou por enfrentamentos, brigas e surras de colegas e pelo menos uma situação em que fui trancado dentro do banheiro e aterrorizado com ameaças. Uma diferença de classe social e de origem (embora não étnica ou racial) passou, então, a ser demarcada pela via da sexualidade e me acompanha desde então. A questão religiosa não era, segundo me lembro, algo tão presente na vivência escolar, ainda que fosse uma escola evangélica localizada no pátio da igreja e ao lado do cemitério.

Apenas quando eu tinha em torno de 20 e 21 anos de idade foi que eu saí do armário e me assumi como homossexual. ${ }^{21}$ Até bem pouco tempo antes disso, apesar de meus eventuais contatos sexuais com outros meninos na adolescência e algumas paixonites que eu identificava como amizade profunda, a própria ideia de uma

\footnotetext{
${ }^{21}$ Utilizo aqui a linguagem disponível à época, sem desconsiderar discussões mais recentes sobre as complexidades do "sair do armário" e "assumir-se" e, também, sobre as problemáticas em torno do termo "homossexual".
} 
orientação sexual homossexual era desconhecida e todas as experiências vividas não passavam, para mim, de brincadeiras e curtições que não interfeririam em nada no meu futuro de homem casado com uma mulher e nas decorrências consideradas "naturais" desse "estado". Por conta de experiências da minha infância e de outras que tive ao longo da minha adolescência e juventude, o processo de sair do armário não foi necessariamente traumático ou doloroso para mim pessoalmente ${ }^{22}$, mas também esse não é o tema aqui. O que quero destacar é que nem o meu pertencimento étnico-racial (evidenciado em características fenotípicas já descritas e no sobrenomes germânicos que compõem a minha árvore genealógica) impediram que a minha sexualidade fosse marcada como "diferente" e isso representasse tratamento desigual em muitas situações na minha família e na minha comunidade, muito antes de eu mesmo ter qualquer consciência em relação a essa questão. Mas, ao mesmo tempo, eu percebia que, mesmo assim, em círculos e espaços menos étnica e racialmente hegemônicos, a minha branquitude e seus derivados ainda me garantiam um certo lugar de privilégio ou pelo menos de aceitação, como é até hoje.

O que me chamava a atenção, já naquela época, era a forte relação estabelecida entre o pertencimento étnico-racial e de classe social (com um nítido recorte religioso) e questões relacionadas à sexualidade. Em todas as vivências mencionadas com relação a pessoas "não-brancas" todos os medos, curiosidades, fantasias e reações negativas, de alguma forma, continham também elementos de sexualização. Por um lado, estava a "decência" (apontada com uma ênfase surpresa) das pessoas e famílias não-brancas elevada à categoria de virtude exemplar, apesar de sua diferença também sempre destacada em relação à raça, etnia e classe social. Por outro lado, estava a "indecência" da minha tia rotulada como prostituta, o amigo negro do meu pai que "fazia coisas sujas" com outros meninos e homens, o suposto caos ou desleixo na organização familiar e comunitária com muitos filhos e muitas filhas nem sempre fruto de relações "legítimas", e até mesmo os ciganos sanguinários e as ciganas sanguinárias, entre muitos outros exemplos, sempre vinculada à raça ou etnia e à classe social da qual eram parte e que deviam ser evitadas a todo custo. ${ }^{23} \mathrm{O}$ elemento religioso era o que dava

\footnotetext{
${ }^{22} \mathrm{O}$ mesmo não pode ser dito em relação à Igreja e à minha família.

23 Althaus-Reid (2001, p. 168) refere-se à "indecência" como "um contradiscurso para o desmascaramento e desnudamento dos pressupostos sexuais construídos para dentro da Teologia da Libertação durante as últimas décadas, mas também hoje ao confrontar questões de globalização e a nova ordem mundial neoliberal. Indecência como um gesto social é extremamente político e erótico, e se relaciona com a construção da identidade do sujeito através de subversão de identidades econômicas, religiosas e políticas".
} 
coesão a esse sistema e marcava essas diferenças, sendo que quem cometia os mesmos “desvios" ou "indiscrições", mas era membro da comunidade religiosa, podia contar com algum tipo de compreensão e até mesmo esquecimento proposital que lhe permitiam seguir sendo parte da comunidade. Nesse sistema social no qual vivi grande parte de minha infância, a escola e a igreja (muito mais do que os saberes e as crenças) produziam e ordenavam sujeitos através de pedagogias em que a branquitude, condições econômicas favoráveis e a heterossexualidade compulsória se articulavam na construção das hierarquias sociais com suas desigualdades, discriminações e violências. Minha estratégia de sobrevivência e, posteriormente, de "fuga" desse contexto, esteve associada à branquitude como valor hegemônico (particularmente no bom desempenho nos estudos e no trabalho), cuja performance sem dúvida continua marcando minhas experiências até hoje, consciente ou inconscientemente.

\section{Conclusão: descolonizar a infância e a educação}

O relato biográfico apresentado não tem como objetivo evidenciar situações conflitantes ou desvantajosas para despertar compaixão ou algum tipo de compreensão em relação às minhas experiências. Também não tem como objetivo destacar formas de superação ou sucesso no manejo de sistemas sociais ou os próprios sistemas socais como capazes de garantir o bem-estar e a felicidade daqueles e daquelas que aprendem a navegar neles. Como evidenciado na introdução, trata-se de apresentar vivências que, quando trazidas para o nível da consciência e da reflexão crítica, podem transformar-se em experiências formadoras e oferecer subsídios para a compreensão de processos complexos que envolvem o entrelaçamento de questões de gênero e sexualidade, raça e etnia, classe social e perceber de que forma o elemento religioso se articula a essas questões.

Aqui o elemento da colonialidade se articula de duas formas: por um lado, evidenciando de que forma os processos coloniais atingem diferentemente indivíduos e grupos sociais; e, por outro lado, de que forma a religião participa desses processos articulando e potencializando questões de gênero e sexualidade, raça e etnia e classe social. A realidade de comunidades teuto-brasileiras no sul do Brasil pode ser percebida e analisada a partir da ideia de pessoas que colonizam (era assim que imigrantes eram chamados e chamadas e se entendiam, embora o termo "colono" tenha vindo a assumir um outro sentido, bastante negativo) e que são, ao mesmo tempo, colonizadas, tanto porque voluntaria ou involuntariamente participam da engrenagem colonizadora, 
quanto porque reproduzem esses valores na organização dos lugares sociais tendo como elemento articulador a branquitude, nesse caso entendida na sua relação com a germanidade e expressando tanto a pertença étnica e racial quanto de classe social, sempre articulada com questões de gênero e sexualidade e envolvida no manto da religiosidade. Não há dúvidas de que há elementos profundamente racistas e xenofóbicos, solidificados ao longo da história das comunidades teuto-brasileiras por diversos motivos, nas experiências formadoras de minha infância e das quais participei e participo de alguma forma. Também não há dúvidas de que a religião, vivenciada na família, na igreja e na escola, justamente por sua referência étnico-racial, participa e determina as pedagogias que ensinam as formas aceitáveis e preferíveis de comportamento e identidade, acionando questões de classe social e de gênero e sexualidade como dispositivos de controle e manutenção da ordem. Reconhecer e evidenciar esses elementos constitui um primeiro passo no processo de descolonização da branquitude como fato social com consequências imediatas e concretas, e das infâncias brancas e seus processos de construção também no campo da educação.

Mas há, nesse exercício, também um outro tipo de elementos que constituem as experiências formadoras com grande potencial descolonizador e que podem contribuir para processos educacionais libertadores da supremacia racista branca e promover outras (des)aprendizagens. E a religião (ou a religiosidade) tem um lugar importante nessa genealogia. Nas experiências narradas neste texto é possível identificar diversos elementos de resistência e articulação de alternativas aos processos hegemônicos coloniais. A relativa naturalidade e tranquilidade com a qual diferenças de raça e etnia, classe social, gênero e sexualidade são experimentadas, pelo menos antes ou enquanto determinadas vivências se processam e são marcadas pelas normas e instituições sociais reguladoras evidencia, por um lado, que a convivência e a relacionalidade experimentadas como parte integrante da construção da identidade e do lugar social na infância podem gerar leituras e posturas críticas e questionadoras, de modo geral próprias dessa fase da vida, ainda que não articuladas necessariamente dessa forma, que produzam outros saberes em relação à diversidade em todas as suas expressões. Por outro lado, ao trazer essas experiências vivenciadas sem a censura repressora ao nível da consciência, transformando-as em experiências formadoras, evidencia, também a realidade de processos mais complexos, menos puros e lineares do que os padrões sociais permitem perceber, os quais geralmente são entendidos como desvios, erros, equívocos, crimes ou pecados. A pluralidade, a fluidez e a excentricidade dessas 
experiências representam, então, formas de resistência e produção de saberes alternativos e ecologicamente articulados com os corpos e suas realidades concretas.

No meu caso específico, a religião e a religiosidade, como elementos fortes da minha formação e da minha identidade étnica e racial, foram fatores que me auxiliaram a entender e questionar as estruturas sociais nas quais estava imerso. A participação em e o cumprimento dos processos institucionais e tradicionais me ajudaram, nem sempre de modo tranquilo ou sem conflitos, a navegar nesse universo, inclusive através da transgressão e perversão de suas normas e regulações. $\mathrm{O}$ contato e o relativo respeito construído em relação a outras experiências religiosas, provavelmente como resultado da postura crítica de minha mãe em relação à igreja e de sua capacidade de articular diferentes perspectivas religiosas, me ensinaram o valor da pluralidade e da diversidade como fatores que engrandecem a experiência humana individual, comunitária e social e expandem a capacidade de estabelecer relações que fomentam a produção de novos conhecimentos e a transformação das estruturas que querem restringi-los e dominá-los. Talvez, então, não seja tão por acaso que essas experiências formadoras da infância tenham me levado à formação e atuação no campo da Teologia e da religião, onde tento continuar minha trajetória de questionamento e produção de novos saberes "indecentes" e "pervertidos". 24

A escola e a igreja, como instituições reguladoras das normas e mantenedoras da ordem social e do status quo, falham ao reprimir as vivências e saberes diversos e plurais ao invés de utilizá-las como ponto de partida para a produção do conhecimento e da cidadania fundados na dialogicidade, na construção coletiva e no reconhecimento das diferenças como ferramentas pedagógicas. Ao abrirem mão de sua capacidade criativa em nome da reprodução de valores e crenças hegemônicas para a regulação dos corpos e de suas práticas, inserem-se na engrenagem que sustenta a colonialidade racista, classista e patriarcal. A saída é descolonizar, inclusive e especialmente a branquitude.

Recebido em: 17-02-2019 Aceito em: 11-03-2019

\section{Referências}

ALTHAUS-REID, Marcella. Indecent theology. London: Routledge, 2001.

\footnotetext{
${ }^{24}$ Segundo Althaus-Reid (2001, p. 119): “Per/versão é apenas o nome para uma outra interpretação, mais enraizada na realidade do que estas representações e paródias das vidas das pessoas, que parecem vir de vinhetas de livros didáticos coloniais".
} 
BAPTISTA, Paulo Agostinho Nogueira. Pensamento Decolonial, Teologias póscoloniais e Teologia da Libertação. Perspectiva Teológica, Belo Horizonte, v. 48, n. 3: 491-517, set./dez. 2016.

BIROLI, Flávia; MIGUEL, Luis Felipe. Gênero, raça, classe: opressões cruzadas e convergências na reprodução das desigualdades. Mediações, Londrina, v. 20, n. 2: 27 55, jul./dez. 2015.

BOBSIN, Oneide. O subterrâneo religioso da vida eclesial: escuta pastoral. Reflexão, Campinas, 41(2):179-197, jul./dez. 2016.

BUTLER, Judith. Gender trouble. New York/London: Routledge, 1999.

BUTLER, Judith. Undoing gender. New York/London: Routledge, 2004.

DREHER, Marin N. Igreja e germanidade: estudo crítico da história da Igreja Evangélica de Confissão Luterana no Brasil. São Leopoldo/Caxias: Sinodal/EDUCS, 1984.

DREHER, Martin N. A Igreja Latino-americana no contexto mundial. Coleção História da Igreja, v. 4. São Leopoldo: Sinodal, 1999.

JOSSO, Marie-Christina. Experiências de vida e formação. Trad. José Claudino e Júlia Ferreira. São Paulo: Cortez, 2004.

JOSSO, Marie-Christine. Caminhar para si. Trad. Albino Pozzer. Coord. Maria Helena Menna Barreto Abrahão. Porto Alegre: EDIPUCRS, 2010.

MUSSKOPF, André S. Identidade masculina e corporeidade: uma abordagem queer. In: MUSSKOPF, André S.; STROHER, Marga J. (Orgs.). Corporeidade, etnia e masculinidade. São Leopoldo: Sinodal, 2005. p. 80-107.

MUSSKOPF, André S. Via(da)gens teológicas. São Paulo: Fonte Editorial, 2012.

NASH, Peter T. Reading race, reading the Bible. Minneapolis: Augsburg Fortress, 2003.

RIBEIRO, Djamila. Quem tem medo do feminismo negro?. São Paulo: Companhia das Letras, 2018.

SEGATO, Rita. La crítica de la colonialidade en ocho ensayos y una antropología por demanda. Ciudad autónoma de Buenos Aires: Prometeo Libros, 2013.

SPARGO, Tamsin. Foucault and Queer Theory. Cambridge/New York: Icon/Totem, 1999.

STRECK, Gisela I. W.; MALACARNE, Ivan Kiper. Adolescência e ritos de passagem: a partir de uma perspectiva do Ensino Confirmatório e Confirmação. Protestantismo em Revista, São Leopoldo, v. 44, n. 1: p. 127-139, 2018.

TOWNES, Emilie. Esquecimento proposital: coloração não-interrogada como lacuna moral. Mandrágora, São Paulo, UMESP, v. 16, n. 16: 13-17, 2010. 
WEBER, Max. A ética protestante e o espírito do capitalismo. Trad. Pietro Nassetti. Coleção Obra-Prima de cada autor. São Paulo: Martin Claret, 2007.

WITT, Osmar. Igreja na migração e colonização. Série Teses e Dissertações, v. 8. São Leopoldo: Sinodal/IEPG, 1996. 